EMPLOYMENT DISPUTES AND THE THIRD PARTY 


\section{Employment Disputes and the Third Party}

Pat Lowry

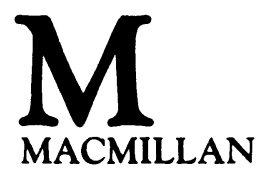


(C) Pat Lowry 1990

Softcover reprint of the hardcover 1st edition 1990 978-0-333-49372-4

All rights reserved. No reproduction, copy or transmission of this publication may be made without written permission.

No paragraph of this publication may be reproduced, copied or transmitted save with written permission or in accordance with the provisions of the Copyright, Designs and Patents Act 1988 , or under the terms of any licence permitting limited copying issued by the Copyright Licensing Agency, 33-4 Alfred Place, London WC1E 7DP.

Any person who does any unauthorised act in relation to this publication may be liable to criminal prosecution and civil claims for damages.

First published 1990

Published by

THE MACMILLAN PRESS LTD

Houndmills, Basingstoke, Hampshire RG21 2XS

and London

Companies and representatives

throughout the world

Typeset by Footnote Graphics,

Warminster, Wiltshire

Printed and bound in Great Britain by

WBC Ltd, Bristol and Maesteg

British Library Cataloguing in Publication Data

Lowry, Pat

Employment disputes and the third party.

1. Great Britain. Industrial relations. Disputes.

Arbitration

I. Title

331.89'143'0941

ISBN 978-1-349-10898-5 ISBN 978-1-349-10896-1(eBook)

DOI 10.1007/978-1-349-10896-1 


\section{Contents}

List of Tables vi

List of Abbreviations vii

Preface ix

Introduction 1

1 Collective Conciliation 13

2 Arbitration 37

3 Mediation, Inquiry, Investigation and Review 90

4 Individual Conciliation 104

5 The Statutory Minimum Wage Question 160

6 From Bridlington to Bournemouth 175

$\begin{array}{ll}\text { Conclusions } & 192\end{array}$

Notes and References $\quad 199$

Index 206 


\section{List of Tables}

1.1 Completed collective conciliation cases, 1975-88 34

2.1 Analysis of CAC awards, 1976-81 46

2.2 Number of boards of arbitration, 1978-88 49

3.1 Number of collective conciliations, arbitrations and mediations, 1978-88 92

3.2 Review bodies, scope and numbers covered (approx.), as at September $1987 \quad 100$

4.1 Summary of industrial tribunal jurisdictions, as at December $1988 \quad 106$

4.2 Jurisdictional analysis of industrial tribunal applications received by ACAS, 1982-8 107

4.3 Individual conciliation cases received and dealt with in all jurisdictions, 1982-8 116

4.4 Electricity supply industry: disciplinary cases referred to arbitration

4.5 Individual conciliation: cases settled and withdrawn as percentage of cases dealt with, 1983-8

4.6 Total cases received by ACAS and number and percentage of non-ITI cases, 1976-88

5.1 Wages councils: inspection and enforcement 164 


\section{List of Abbreviations}

ACAS Advisory, Conciliation and Arbitration Service

AEU

AFPRB

Amalgamated Engineering Union

ASLEF Associated Society of Locomotivemen, Enginemen and

Review Body on Armed Forces Pay

Firemen

BT British Telecom

CAC Central Arbitration Committee

CBI

CCSU

Confederation of British Industry

CIR

Council of Civil Service Unions

COHSE Confederation of Health Service Employees

COIT

CSAT

Central Office of the Industrial Tribunals

DDRB

DE

Civil Service Arbitration Tribunal

ECA

Review Body on Doctors' and Dentists' Remuneration

EAT

Department of Employment

EC

Electrical Contractors' Association

EEF

Employment Appeal Tribunal

EETPU Electrical, Electronic, Telecommunication and

European Community

Engineering Employers' Federation

Plumbing Union

GEC General Electric Co. Ltd.

LRT London Regional Transport

NACODS National Association of Colliery Overmen, Deputies and Shotfirers

NALHM National Association of Licensed House Managers

NAPRB Review Body for Nursing Staff, Midwives, Health

Visitors and Professions Allied to Medicine

NAT National Arbitration Tribunal

NCB National Coal Board

NGA National Graphical Association

NHS National Health Service

NUM National Union of Mineworkers

NUPE National Union of Public Employees

NUR National Union of Railwaymen

OME Office of Manpower Economics

POAT Post Office Arbitration Tribunal 
POAMT Post Office Arbitration and Mediation Tribunal

PRP Pharmacists' Review Panel

RSNT Railway Staff National Tribunal

SJIC Statutory Joint Industrial Council

SOGAT Society of Graphical and Allied Trades

SRB Special Review Body (TUC)

STUC Scottish Trades Union Congress

TGWU Transport and General Workers' Union

TSRB Review Body on Top Salaries

TSSA Transport and Salaried Staffs Association

TUC Trades Union Congress

UCW Union of Communication Workers

UDM Union of Democratic Mineworkers 


\section{Preface}

This book covers more than just the ACAS involvement in industrial disputes. My thanks are therefore due not just to those former ACAS colleagues who have assisted me so enormously but also to all those others - in employers' associations, trade unions, nationalised industries and private sector companies - on whose time I have so shamelessly trespassed and whose patience I have so sorely tried. To them all, as well as to officials in the Department of Employment and the Office of Manpower Economics, I am most grateful.

I am particularly indebted to Jean Hiltrop, David Burrill and Alice Brown for allowing me to quote some of the results of their research work for ACAS into certain aspects of the Service's conciliation and arbitration activities. At Warwick University Linda Dickens offered me some much needed help and advice in the area of individual employment rights in which she is so widely acknowledged an expert.

As a result of all this assistance I have tried to be as factually accurate as a rapidly changing scene permits. Needless to say, the conclusions and opinions are my own. In a book which dwells, in part, on matters concerning equal opportunities in employment, it is particularly important to stress that I have observed the convention of using 'he' and 'him' to cover both genders, save of course where the context is so obviously concerned with one sex only.

PAT LOWRY 